\title{
Identifying the niche controlling melanocyte differentiation
}

\author{
Manuel Zocco ${ }^{1}$ and Cédric Blanpain ${ }^{1,2}$ \\ ${ }^{1}$ Université Libre de Buxelles (ULB), Stem Cells and Cancer Laboratory, 1070 Brussels, Belgium; ${ }^{2}$ WELBIO, Université Libre de \\ Bruxelles (ULB), 1070 Bruxelles, Belgium
}

\begin{abstract}
Melanocytes present in hair follicles are responsible for their pigmentation. Melanocyte differentiation and hair pigmentation depend on the stem cell factor (SCF)/c-Kit signaling pathway, but the niche that regulates melanocyte differentiation is not well characterized. In this issue of Genes \& Development, Liao and colleagues (pp. 744-756) identify Krox $20^{+}$-derived cells of the hair shaft as the niche and the essential source of SCF required for melanocyte maturation. This study delineates the niche factors regulating melanocyte differentiation and hair pigmentation and opens up new avenues to further characterize the cross-talk between the hair follicle and melanocytes that controls melanocyte maintenance and differentiation.
\end{abstract}

Melanocytes are pigment-producing cells that protect the skin epidermis from UV damage and give color to the hairs. To do so, melanocytes produce melanin, a pigment that has a dual function: It absorbs UV light and thus protects against DNA damage induced by UV radiation and acts as an antioxidant scavenger against genotoxic reactive oxygen species (ROS) (Natarajan et al. 2014). Melanin is produced in particular endosomal-derived organelles called melanosomes that, once mature, are transferred to nearby epidermal keratinocytes, inducing skin and hair pigmentation (Mort et al. 2015). Hair pigmentation is due to the action of melanocytes residing in the hair matrix transferring melanosomes to the hair shaft progenitor cells, which in turn terminally differentiate to form the highly keratinized and pigmented hair structure. Hair follicles (HFs) alternate cycles of growth and degeneration throughout the life of the animal (Blanpain and Fuchs 2009). In the mouse epidermis, the differentiated melanocytes of the HFs express c-Kit, the tyrosine kinase receptor for the stem cell factor (SCF) cytokine (Mort et al. 2015). Previous studies identified two distinct populations of melanocytes based on the expression of c-Kit: $\mathrm{c}-\mathrm{Kit}^{+}$melanocytes located in the hair matrix and c-Kit ${ }^{-}$melanocytes located around the bulge area, the location of HF and me-

[Keywords: stem cell factor (SCF); hair pigmentation; hair shaft progenitor cell; hair follicle stem cell; hair matrix; KROX20]

Corresponding author: cedric.blanpain@ulb.ac.be

Article is online at http://www.genesdev.org/cgi/doi/10.1101/gad.300665. 117. lanocyte stem cells (Nishimura et al. 2002; Blanpain and Fuchs 2009). The maintenance of the HF melanocytes

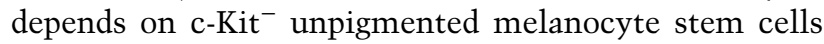
residing in the HF bulge (Nishimura et al. 2002). Specific signals activate the melanocyte stem cells to migrate into the hair matrix and differentiate into melaninproducing cells. Among the best-characterized signaling pathways controlling melanocyte functions, SCF/c-Kit signaling activates melanocyte precursor proliferation, migration, and differentiation into pigment-producing cells (Botchkareva et al. 2001). Mice with an inactivating mutation in c-Kit showed defects of hair color (Reith et al. 1990), and monoclonal antibodies blocking c-Kit block hair pigmentation for at least one hair cycle (Nishikawa et al. 1991; Botchkareva et al. 2001; Yoshida et al. 2001; Nishimura et al. 2002), supporting the importance of the SCF/c-Kit signaling pathway for melanocyte proliferation, differentiation, and hair shaft pigmentation.

Despite the well-characterized function of the SCF/cKit signaling pathway in regulating melanocyte differentiation, the cellular source of SCF and the niche involved in melanocyte differentiation and hair pigmentation remain elusive. In this issue of Genes \& Development, Liao et al. (2017) report the identification of the progeny of hair shaft progenitors expressing the transcription factor Krox20 as the source of Scf required for melanocyte differentiation and forming the niche required for hair pigmentation (Fig. 1).

Liao et al. (2017) discovered that the conditional knockout (cKO) of $S c f\left(S c f^{\mathrm{fl} / \mathrm{GFP}}\right)$ in the Krox20-derived cell lineages using a constitutively expressed CRE recombinase under the control of the Krox20 promoter (Krox20CRE) causes premature postnatal hair graying starting at $\sim 2$ mo. As Krox20 is expressed in different lineages in the skin, including Schwann cells and HF keratinocytes (Gambardella et al. 2000), the investigators used different CRE mice to delete $S c f$ independently in these different lineages. Deletion of $S c f$ in Schwann cells or melanocytes has no effect on hair pigmentation, ruling out that the

(C) 2017 Zocco and Blanpain This article is distributed exclusively by Cold Spring Harbor Laboratory Press for the first six months after the full-issue publication date (see http://genesdev.cshlp.org/site/misc/ terms.xhtml). After six months, it is available under a Creative Commons License (Attribution-NonCommercial 4.0 International), as described at http://creativecommons.org/licenses/by-nc/4.0/. 




Figure 1. The niche for hair follicle pigmentation. During melanocyte maturation, melanocyte precursors migrate from their bulge stem cell niche to the hair matrix compartment. In the matrix, hair shaft precursors (in green) generate a niche for melanocyte differentiation by producing SCF (in blue). Melanocyte precursors (in yellow) are activated by SCF and differentiate in the upper compartment of the hair matrix, delimited by the Line of Auber. Differentiated melanocytes (in yellow with red outline) transfer their melanosomes to pigment the hair shaft precursors (in green). While receiving melanin, pigmented hair shaft precursors (in brown) differentiate to form the pigmented hair shaft. By impairing SCF production in hair shaft precursors, the investigators showed the blockade of melanocyte differentiation in the matrix, resulting in the lack of pigmentation of the hair shaft.

source of SCF that promotes hair pigmentation is coming from these lineages. However, deletion of Scf using K14Cre mice, which targets all keratinocytes during the early stage of epidermal development, induces a complete loss of pigmentation in the first wave of HF morphogenesis, supporting the notion that Scf expression in keratinocytes is required to induce hair pigmentation in a non-cellular-autonomous manner.

To get a better insight into which specific cell subpopulations within the skin epidermis are responsible for hair pigmentation, the investigators performed a careful temporal analysis of Krox20 lineage tracing using the Krox20CRE/Rosa26-LacZ mice. They found that at postnatal day 0 (P0)/P2, Krox20CRE marks the upper part of the HF, corresponding to the infundibulum that connects the HF to the interfollicular epidermis. Later, during postnatal development around P12, Krox20CRE in addition marks the outer root sheath (ORS) cells and the cells of the matrix and precortex, which give rise to the terminally differentiated hair shaft. The relatively late expression of Krox20 during the first wave of HF morphogenesis explains the discrepancy in the temporal appearance of the hair graying phenotype between K14CRE Scf cKO mice, which begins in the first wave of hair formation, whereas the beginning of the hair graying phenotype appears during the second hair cycle in Krox20CRE Scf cKO mice.
Using Scf-GFP reporter mice combined with Krox20CRE/Rosa26-LacZ lineage tracing, Liao et al. (2017) convincingly showed that $S c f$ is expressed in the hair shaft cells and not in ORS cells, strongly suggesting that the Krox $20^{+}$-derived hair shaft cells are the main source of Scf in adult mice and constitute the niche for hair pigmentation. Consistent with this notion, overexpression of Scf using K14-Scf transgenic mice-which expressed membrane-bound Scf in all K14-expressing cells, encompassing the basal keratinocytes from the interfollicular epidermis and all upper and lower ORS cells but not the hair matrix and hair shaft cells-fails to rescue the hair graying phenotype in K14CRE and Krox20CRE Scf cKO mice.

To determine whether Scf deletion impairs melanocyte maintenance, migration, or differentiation, Liao et al. (2017) investigated the presence and differentiation of melanocytes in the HF in the absence of Scf. Dct, a marker of melanocytes, is completely absent in the K14CRE/Scf cKO mice and strongly reduced in Krox20CRE/Scf cKO mice in the lower HF, including the hair matrix and hair shaft, supporting the essential role of SCF in promoting Dct expression in melanocytes. In wild-type mice, c-Kit marks both mature (upper matrix and hair shaft) and immature (lower matrix) melanocytes. Interestingly, in the absence of SCF in all epidermal lineages (K14CRE/Scf $\mathrm{cKO}$ ), differentiated c-Kit ${ }^{+}$melanocytes were completely 
absent in the differentiated melanocyte compartment, whereas the immature $\mathrm{c}-\mathrm{Kit}^{+}$melanocyte precursors were unaffected by the absence of Scf, demonstrating that Scf is necessary for melanocyte terminal differentiation but has no essential role in promoting the survival and migration of melanocyte precursors from their bulge niche to the matrix transit-amplifying compartment.

In conclusion, this study thoroughly characterizes the niche and the source of Scf required for HF pigmentation and demonstrates that hair shaft cells are the principal source of Scf that is required for melanocyte terminal differentiation. Future studies will be important to further characterize the molecular mechanisms that regulate the maintenance of melanocyte stem cells within their bulge niche and the signals that activate these cells at each round of hair cycle and regulate the initial migration and expansion of melanocyte precursors before they reach the newly discovered hair shaft niche that promotes their final maturation.

\section{References}

Blanpain C, Fuchs E. 2009. Epidermal homeostasis: a balancing act of stem cells in the skin. Nat Rev Mol Cell Biol 10: 207-217.

Botchkareva NV, Khlgatian M, Longley BJ, Botchkarev VA, Gilchrest BA. 2001. SCF/c-kit signaling is required for cyclic regeneration of the hair pigmentation unit. FASEB I 15: 645-658.
Gambardella L, Schneider-Maunoury S, Voiculescu O, Charnay P, Barrandon Y. 2000. Pattern of expression of the transcription factor Krox-20 in mouse hair follicle. Mech Dev 96: 215-218.

Liao CP, Booker RC, Morrison SJ, Le QL. 2017. Identification of hair shaft progenitors that create a niche for hair pigmentation. Genes Dev (this issue). doi: 10.1101/gad.298703.117.

Mort RL, Jackson IJ, Patton EE. 2015. The melanocyte lineage in development and disease. Development 142: 620-632.

Natarajan VT, Ganju P, Ramkumar A, Grover R, Gokhale RS. 2014. Multifaceted pathways protect human skin from UV radiation. Nat Chem Biol 10: 542-551.

Nishikawa S, Kusakabe M, Yoshinaga K, Ogawa M, Hayashi S, Kunisada T, Era T, Sakakura T, Nishikawa S. 1991. In utero manipulation of coat color formation by a monoclonal antic-kit antibody: two distinct waves of c-kit-dependency during melanocyte development. EMBO J 10: 2111-2118.

Nishimura EK, Jordan SA, Oshima H, Yoshida H, Osawa M, Moriyama M, Jackson IJ, Barrandon Y, Miyachi Y, Nishikawa S-I. 2002. Dominant role of the niche in melanocyte stem-cell fate determination. Nature 416: 854-860.

Reith AD, Rottapel R, Giddens E, Brady C, Forrester L, Bernstein A. 1990. W mutant mice with mild or severe developmental defects contain distinct point mutations in the kinase domain of the c-kit receptor. Genes Dev 4: 390-400.

Yoshida H, Grimm T, Nishimura EK, Nishioka E, Nishikawa S-I, Kunisada T. 2001. Review: melanocyte migration and survival controlled by SCF/c-kit expression. I Investig Dermatology Symp Proc 6: 1-5. 


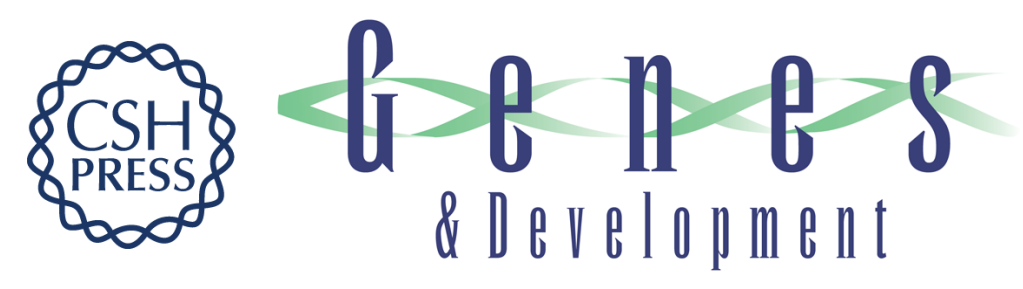

\section{Identifying the niche controlling melanocyte differentiation}

\section{Manuel Zocco and Cédric Blanpain}

Genes Dev. 2017, 31:

Access the most recent version at doi:10.1101/gad.300665.117

\section{Related Content Identification of hair shaft progenitors that create a niche for hair pigmentation Chung-Ping Liao, Reid C. Booker, Sean J. Morrison, et al. Genes Dev. April , 2017 31: 744-756}

References This article cites 10 articles, 3 of which can be accessed free at: http://genesdev.cshlp.org/content/31/8/721.full.html\#ref-list-1

Articles cited in: http://genesdev.cshlp.org/content/31/8/721.full.html\#related-urls

Creative This article is distributed exclusively by Cold Spring Harbor Laboratory Press for the first Commons License six months after the full-issue publication date (see http://genesdev.cshlp.org/site/misc/terms.xhtml). After six months, it is available under a Creative Commons License (Attribution-NonCommercial 4.0 International), as described at http://creativecommons.org/licenses/by-nc/4.0/.

Email Alerting Receive free email alerts when new articles cite this article - sign up in the box at the top Service right corner of the article or click here.

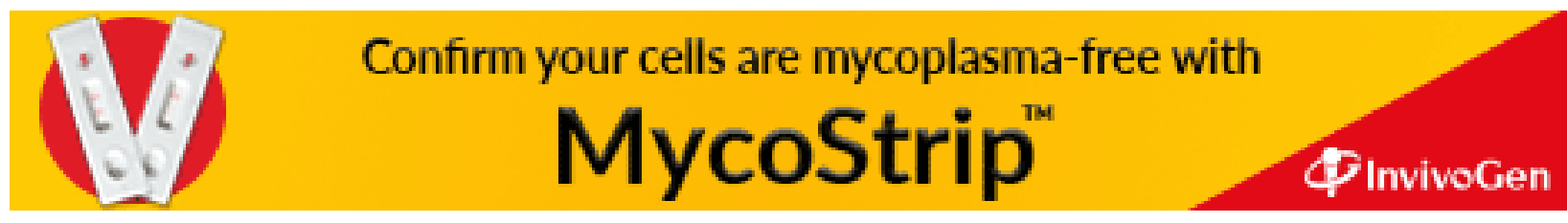

